\title{
Wip1 and p53 contribute to HTLV-1 Tax-induced tumorigenesis
}

\author{
Linda Zane ${ }^{1}$, Junichiro Yasunaga ${ }^{2}$, Yu Mitagami ${ }^{2}$, Venkat Yedavalli ${ }^{1}$, Sai-Wen Tang ${ }^{1}$, Chia-Yen Chen ${ }^{1}$, Lee Ratner ${ }^{3}$, \\ Xiongbin $\mathrm{Lu}^{4}$ and Kuan-Teh Jeang ${ }^{1^{*}}$
}

\begin{abstract}
Background: Human T-cell Leukemia Virus type 1 (HTLV-1) infects 20 million individuals world-wide and causes Adult T-cell Leukemia/Lymphoma (ATLL), a highly aggressive T-cell cancer. ATLL is refractory to treatment with conventional chemotherapy and fewer than $10 \%$ of afflicted individuals survive more than 5 years after diagnosis. HTLV-1 encodes a viral oncoprotein, Tax, that functions in transforming virus-infected T-cells into leukemic cells. All ATLL cases are believed to have reduced p53 activity although only a minority of ATLLs have genetic mutations in their p53 gene. It has been suggested that p53 function is inactivated by the Tax protein.

Results: Using genetically altered mice, we report here that Tax expression does not achieve a functional equivalence of p53 inactivation as that seen with genetic mutation of p53 (i.e. a p53 $53^{-/-}$genotype). Thus, we find statistically significant differences in tumorigenesis between $\operatorname{Tax}^{+} p 53^{+/+}$versus $\operatorname{Tax}^{+} p 53^{-/-}$mice. We also find a role contributed by the cellular Wip1 phosphatase protein in tumor formation in Tax transgenic mice. Notably,

$\operatorname{Tax}^{+} \mathrm{Wip}^{-1-}$ mice show statistically significant reduced prevalence of tumorigenesis compared to Tax $^{+}$Wip $^{+/+}$counterparts.
\end{abstract}

Conclusions: Our findings provide new insights into contributions by p53 and Wip1 in the in vivo oncogenesis of Tax-induced tumors in mice.

\section{Background}

Human T-cell Leukemia Virus type 1 (HTLV-1) is the first identified human retrovirus. The virus belongs to the deltaretrovirus family and is the etiological agent of a highly aggressive neoplastic disease, Adult T-cell Leukemia/Lymphoma (ATLL), and inflammatory diseases including HTLV-1 Associated Myelopathy (HAM)/Tropical Spastic Paraparesis (TSP), uveitis, infective dermatitis and myositis [1-9]. HTLV-1 infects approximately 20 million individuals world-wide, and 1-5\% of infected individuals will develop ATLL after a long latency period of 20 to 60 years [1].

HTLV-1 encodes a viral Tax oncoprotein. The singular expression of Tax is sufficient to transform primary rodent cells [10] and potentially human embryonic stem cells [11], immortalize human primary $\mathrm{T}$ lymphocytes $[12,13]$, and induce tumors in transgenic mice [14-17].

\footnotetext{
* Correspondence: KJEANG@nih.gov

${ }^{1}$ Molecular Virology Section, Laboratory of Molecular Microbiology, the National Institutes of Allergy and Infectious Diseases, the National Institutes of Health, Bethesda, Maryland 20892-0460, USA

Full list of author information is available at the end of the article
}

Tax confers pro-proliferative and pro-survival properties to HTLV-1 infected cells [18-20] by pleiotropically activating effector proteins including the Cyclic AMP Responsive Binding Protein (CREB) and CBP/p300 [21-24], Nuclear Factor kappa-B (NF-kB) [25-29], Cyclin-Dependant Kinases (CDKs) [30-33], and Akt [34-36] amongst others. Tax also triggers DNA damage [37-42]. In transforming a normal T-cell into a leukemic cell, it is believed that Tax must also neutralize cellular checkpoints (e.g. p53 and mitotic spindle assembly checkpoint) that act to censor DNA damage $[43,44]$ and aneuploidy $[45,46]$.

p53 is a DNA-binding transcription factor that plays a key role in cell cycle regulation, apoptosis, and DNA repair [47]. The p53 gene is recognized as one of the most important tumor suppressor genes and is frequently mutated in human tumors including hematologic malignancies [48-50]. In many human malignancies, the frequency of p53 genetic mutation is $250 \%$ [51,52]; however, the frequency of mutated p53 in ATL patients is reported to be around $15 \%$ [53-58], suggesting that loss of p53 activity in ATL may largely arise through a

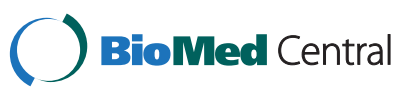


mechanism other than genetic mutation. Several in vitro studies in different cell types have shown that Tax represses p53 activity [59-65]. Various mechanisms have been proposed for Tax-inactivation of $\mathrm{p} 53$. Indeed, it has been suggested that Tax inactivates p53 by acting through either the CREB [62] or the NF-kB $[66,67]$ pathway; however, it has also been noted that neither mechanism satisfactorily explains Tax-p53 interaction [65], leaving the question of how Tax effectively disables p53 function incompletely answered.

Here, we have conducted in vivo experiments in mice to address two questions. First, we have assessed the effectiveness of Tax mediated inactivation of p53 versus inactivation of p53 by genetic mutations. Second, we have characterized Wip1 as a cooperating in vivo Tax co-factor in p53 inactivation. Using various genetically altered mice, we show that Tax inactivation of p53 is functionally less stringent than p53 inactivation by genetic mutation, and we report that the cellular Wip1 phosphatase protein collaborates functionally with Tax in inhibiting p53 activity.

\section{Results}

$\operatorname{Tax}^{+} p 53^{-/-}$mice show reduced tumor free survival compared to $\operatorname{Tax}^{+} p 53^{+/+}$

In ATLs, p53 genetic mutations are less frequent than those seen in many other cancers $[53,54,58]$. It has been reasoned that the ability of Tax to inacti-vate p53 function [55] explains why ATL cells may not need to inactivate p53 by genetic mutation. Nevertheless, it has not been clearly characterized whether Tax inactivation of p53 is quantitatively equivalent to inactivation of p53 by genetic mutation. We sought to investigate this issue using gene-tically altered mice. Accordingly, we crossed Tax transgenic mice [15] with $p 53^{-/-}$mutant mice [68] to generate $\operatorname{Tax}^{+} p 53^{-/-}$, $\operatorname{Tax}^{+} p 53^{+/-}$and $\operatorname{Tax}^{+} p 53^{+/+}$progenies. We analyzed the genotypes (Figure 1) of the offsprings and monitored the animals over >300 days for tumor development (Figure 2). Tumor-free survival for $\operatorname{Tax}^{+} p 53^{-/-}$mice (Figure 2A) was significantly worse compared to $\operatorname{Tax}^{+} p 53^{+/-}$and $\operatorname{Tax}^{+} p 53^{+/+}$counterparts ( $\mathrm{p}<0.0001$; Gehan-Breslow-Wilcoxon test). There were no statistically significant differences in the levels of Tax expression between these two categories of $\mathrm{Tax}^{+}$mice supporting that the difference in tumor-free survival was not due to levels of Tax expression (Additional file 1: Figure S1). Interestingly, no significant difference in tumor-free survival between $\operatorname{Tax}^{+} p 53^{+/-}$and $\operatorname{Tax}^{+} p 53$ $+/+$ mice was found ( $\mathrm{p}=0.7093$; Gehan-BreslowWilcoxon test); this finding agrees with our previous tumorigenesis study of $p 53^{+/-}$and $p 53^{+/+}$mice [69] that, in the context of our mice, we find no significant functional difference between homozygosity versus heterozygosity in wild type p53. Thus, our finding of a distinct difference in tumor-free survival of $\operatorname{Tax}^{+} p 53^{-/-}$ compared to $\operatorname{Tax}^{+} p 53^{+/+}$mice indicates that Tax inactivation of $\mathrm{p} 53$ (i.e. $\operatorname{Tax}^{+} p 53^{+/+}$) is qualitatively less stringent than genetic inactivation of $\mathrm{p} 53$ (i.e. $\operatorname{Tax}^{+} p 53^{-/-}$).
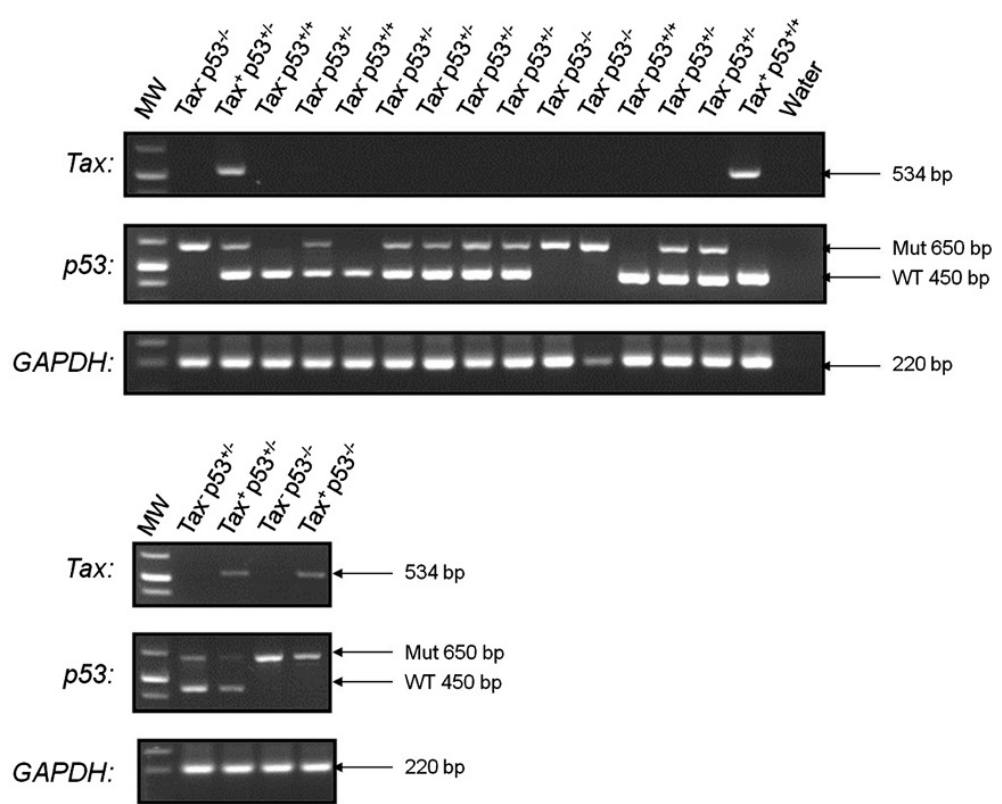

Figure 1 Genotyping of p53KO/Tax Tg mice. p53 primers distinguish between WT and mutant p53 alleles with PCR products of 450 and 650 bp in size (top), respectively. Middle panel shows the detection of Tax DNA (534 bp), and the bottom panel shows PCR control detecting cell endogenous GAPDH gene (220 bp). Mut, mutant ; WT, wild type. Tax, p53, and GAPDH signals are as indicated. 
A

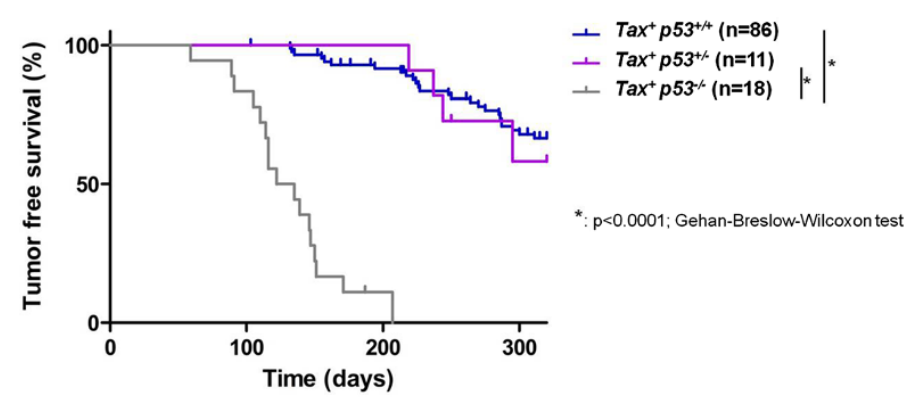

B

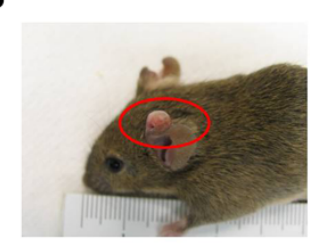

C

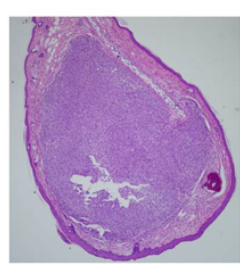

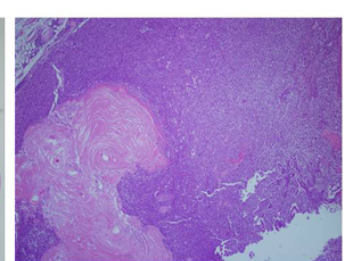

Figure 2 Statistically significant reduction of tumor-free survival in $\operatorname{Tax}^{+} p 53^{-/-}$mice compared to $\operatorname{Tax}^{+} p 53^{+/+}$. (A) Tumor-free survival curves show decreased tumor free survival in $\operatorname{Tax}^{+} p 53^{-/-}$mice compared to Tax ${ }^{+} p 53^{+/-}$or $\operatorname{Tax}^{+} p 53^{+/+}$animals. Statistical significance $\left(^{*}\right.$ : $\left.p<0.0001\right)$ between $\operatorname{Tax}^{+} p 53^{-/-}$and either $\operatorname{Tax}^{+} p 53^{+/-}$or $\operatorname{Tax}^{+} p 53^{+/+}$mice was determined using Gehan-Breslow-Wilcoxon test. (B) A Tax transgenic mouse with an ear tumor is shown for illustration. (C) Examples of tumor histology [hematoxylin and eosin (H\&E) staining] from Tax ${ }^{+} p 53^{+/+}$mice are shown. Example of a pleomorphic ear sarcoma from a Tax ${ }^{+} p 53^{+/+}$mouse; (left): expansive soft tissue tumor located in peripheral connective tissue of the ear beneath the supportive cartilage; example of a hind leg pleomorphic histiocytic sarcoma and glandular adenocarcinoma with squamous hyperkeratosis from a Tax $p 53^{+/+}$mouse (right): the sarcoma consisted primarily of histiocytic tumor cells with dispersed round cells, sparse spindle cells and neutrophilic granulocytes. Similar tumors are also seen in $\operatorname{Tax}^{+} p 53^{-/-}$mice.

\section{Wip1 phosphatase modulates p53 activity}

We wished next to understand how other non-genetic means of inactivating p53 might cooperate with Tax in cellular transformation. Wip1 (Wild-type p53-induced phosphatase 1) is a human protein phosphatase that has been shown to be amplified and over-expressed in multiple human cancers and has been suggested to exhibit oncogenic potential [70]. A plausible mechanistic scenario could be that Wip1 acts to inhibit p53 activity, thereby contributing to tumorigenesis. Through its ability to inhibit p53 tumor suppressor function, Wip1, like Tax, may reduce the selective pressure for $p 53$-inactivating mutations during cancer progression [71,72]. To check the effect of Wip1 on p53, we assessed how its over-expression affects p53's transcriptional activity. Accordingly, we transfected human HCT-116 cells with a luciferase reporter plasmid containing 13 copies of a p53 consensus binding site (pG13-Luc; [73]) together with a Wip1 expression plasmid (Figure 3A and B), or we transfected pG13-Luc with a Tax expression plasmid-alone, or we transfected pG13-Luc with both Wip1 and Tax expression plasmids (Figure 3A and B). Under our transfection conditions, both Wip1-alone and Tax-alone with pG13-Luc robustly repressed the expression of the reporter plasmid by more than $40 \%\left(p=1.496 \times 10^{-5}\right.$ for Wip1-alone; $\mathrm{p}=7.62 \times 10^{-5}$ for Tax-alone; t-test) (Figure 3A). Of note, the co-transfection of Wip1 with Tax repressed pG13-Luc expression by an additional $20 \%$ and $15 \%$ over that achieved with Tax-alone $(\mathrm{p}=0.0025 ; \mathrm{t}$-test $)$ or Wip1 alone $(\mathrm{p}=0.019 ; \mathrm{t}$-test $)$ (Figure $3 \mathrm{~A})$. When the transfections were performed in the presence of co-introduced exogenous p53, we again observed a statistically significant repression of p53 transcriptional activity; here, we saw $>60 \%$ repre-ssion of pG13Luc expression after transfection with Wip1-alone $(\mathrm{p}=3.27$ $\times 10^{-5}$; t-test) or Tax-alone ( $\mathrm{p}=2.22 \times 10^{-5}$; $\mathrm{t}$-test) (Figure 3B). In the presence of exogenously introduced $\mathrm{p} 53$, the cotransfection of Wip1 and Tax repressed pG13-Luc expression by more than $50 \%$ over that achieved with Tax-alone $\left(\mathrm{p}=7.43 \times 10^{-5}\right.$; t-test $)$ or Wip1-alone $\left(\mathrm{p}=1.25 \times 10^{-4} \mathrm{t}\right.$-test $)$ (Figure 3B). In Figure 3C, the expression of the transfected plasmids used in Figures 3A and 3B was checked by Western blotting. Taken together, these findings support that Wip1 and Tax cooperate in overall p53 inactivation.

Transient over-expression assays generally are imperfect reflections of physiological regulation. To ask in a more physiological manner how endogenous Wip1 expression regulates $\mathrm{p} 53$ activity, we independently isolated several primary MEF clones from $\mathrm{Wip1}^{-/-}$knock-out mice [74] and their $\mathrm{Wipl}^{+/+}$wild type siblings (genotyping examples of MEFs are shown in Figure 3D, top). We then compared cell endogenous p53 activity in several independently isolated $\mathrm{Wip1}^{-/-}$MEFs to other independently isolated control Wip1 ${ }^{+/+}$MEFs employing either the pG13-Luc reporter assay (Figure 3D, bottom) or by determining the mRNA expression levels of a known p53responsive target gene, p21 ${ }^{\mathrm{WAF} 1 / \mathrm{CIP1} 1}$ (Figure 3E). Notably, 
A

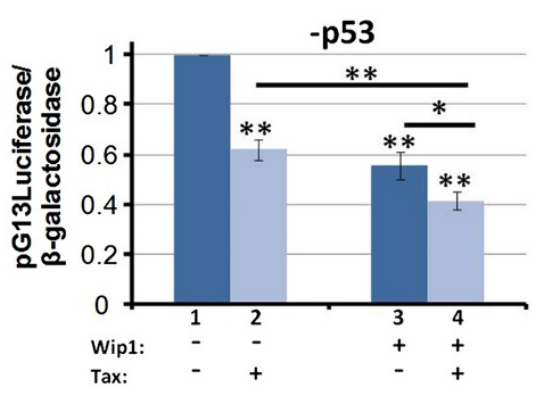

C
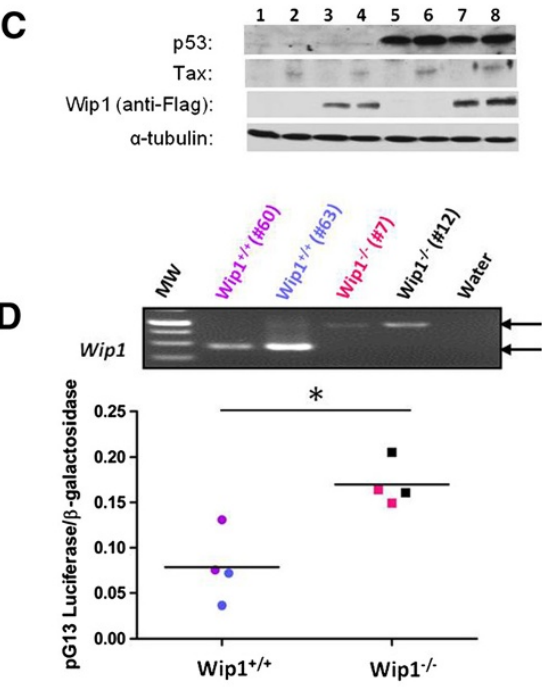

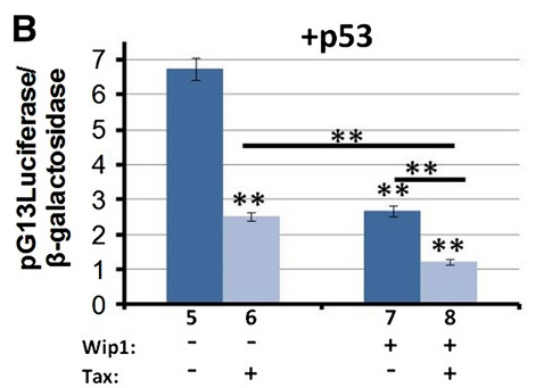

E
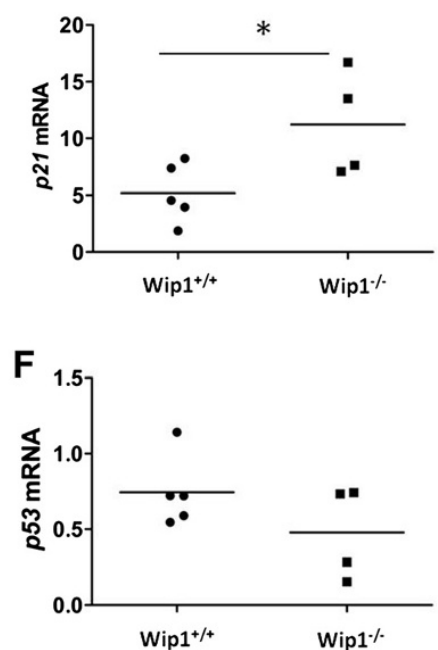

Figure 3 Wip1 phosphatase attenuates p53 activity. Wip1 and/or Tax expression reduces p53 transactivation of a pG13Luc-reporter in HCT-116 cells in the absence $(\mathbf{A})$ or in the presence (B) of exogenous p53 $(0.8 \mu \mathrm{g})$. HCT-116 cells were transfected with $0.2 \mu \mathrm{g}$ of Tax and/or $0.75 \mu \mathrm{g}$ of Wip1 expression plasmid (*: $0.01 \leq p \leq 0.05 ;{ }^{* *}: \mathrm{p}<0.05$; t-test). (C) Cell lysates from a representative experiment were subjected to immunoblotting using anti-p53, anti-Tax, anti-Flag and anti-a-tubulin as indicated. The lane numbers of the samples in each case corresponds to the lane numbers indicated in panels (A) and (B). (D) Analysis of cell endogenous p53 activity was conducted using the pG13-Luciferase plasmid in $\mathrm{Wip}^{-/-}$and $\mathrm{Wip}^{+/+}$Mouse Embryonic Fibroblasts (MEF). Top panel shows PCR genotypic characterizations of two independent Wip1 ${ }^{+/+}$ $(60,63)$ and two independent Wip1 $1^{-1-}(7,12)$ MEFs; each was assayed twice in pG13Luc-reporter assays. Bottom graph shows the luciferase assays. All luciferase activities were normalized to a co-transfected $\beta$-galactosidase reporter. Statistical significance was determined using t-test (*: $^{*}=0.0076$ ). (E) Analyses of cell endogenous p21 and (F) p53 mRNAs in 5 independent Wip $1^{+/+}$(left) and 4 independent Wip $1^{-/-} \mathrm{MEFs}$. Real-time RT-PCR analyses of $p 53$ and $p 21$ and GAPDH (internal standard) transcripts were performed in Wip $1^{-/-}$and Wip $1^{+/+}$MEFs. There was no statistically significant difference in p53 mRNA levels, while p21 mRNA levels were significantly different between Wip ${ }^{+/+}$and Wip $1^{-/-}$MEFs (*: $\mathrm{p}=0.0425 ;$ t-test)

the Wip1 ${ }^{-/-}$MEFs showed statistically significant higher levels of $\mathrm{pG13}$-Luc expression $(\mathrm{p}=0.0076 ; \mathrm{t}$-test $)$ and higher levels of 21 mRNA ( $\mathrm{p}=0.0425$; $\mathrm{t}$-test) than the Wip1 $^{+/+}$MEFs, suggesting that cell endogenous Wip1 does physiologically reduce p53 function in primary cells (Figures 3D and E). This regulation of p53 by Wip1, however, does not occur at the level of transcription because there was no statistically significant difference in the amounts of p53 mRNA in Wip1 ${ }^{+/+}$versus Wip1 $1^{-/-}$MEFs (Figure 3F).

\section{Wip1 deficiency reduces Tax-tumorigenesis}

The above results show that both Wip1 and Tax inactivate p53 function. Next, we asked how the two events might cooperate in tumorigenesis. To address their functional collaboration, we crossed Tax transgenic mice with $\mathrm{Wipl}^{+/+}$or $\mathrm{Wipl}^{-/-}$mice. Various genotypic offsprings were obtained from these crosses (genotyping examples are shown in Figure 4A), and the animals were monitored for tumorigenesis over 300 days (Figure 4B). Interestingly, $\mathrm{Wipl}^{+/-}$and $\mathrm{Wipl}^{-/-}$mice that express Tax showed significantly better tumor-free survival than $\mathrm{Wip1}^{+/+}$animals that express Tax (Figure 4B). Indeed, tumor-free survivals were statistically different between $\mathrm{Tax}^{+} \mathrm{Wip}^{-/-}$( $\mathrm{p}=0.0319$; Gehan-Breslow-Wilcoxon test) or Tax $^{+}$Wip1 $^{+/-}$mice ( $\mathrm{p}=0.0396$; Gehan-Breslow-Wilcoxon test) compared to $\mathrm{Tax}^{+} \mathrm{Wip1}^{+/+}$mice. In view of findings above that p53 activity is higher in $\mathrm{Wip1}^{-/-}$MEFs 


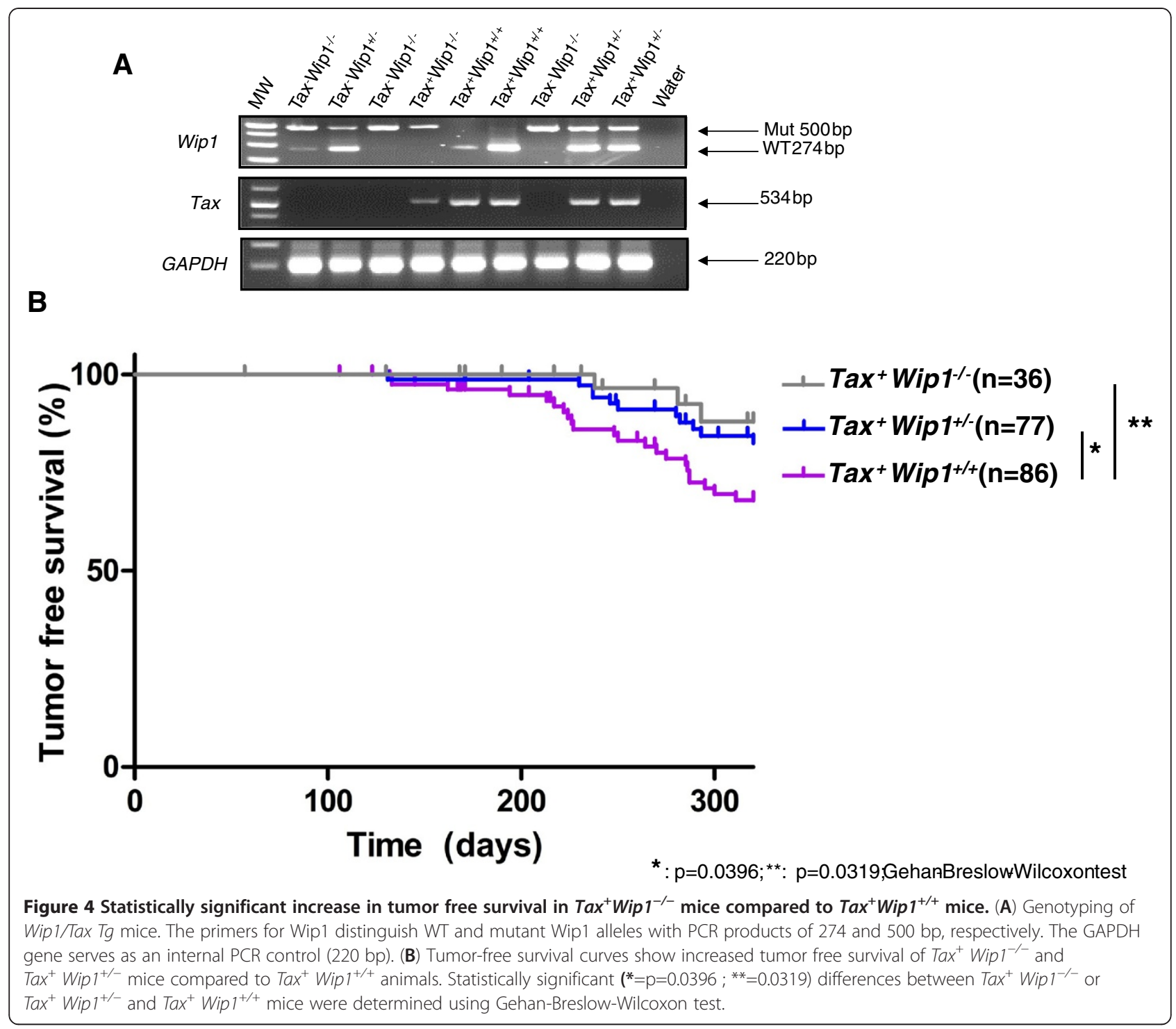

compared to $\mathrm{Wipl}^{+/+}$MEFs; one interpretation of these in vivo tumor results is that homozygous loss of Wip1 (i.e.Tax ${ }^{+} \mathrm{Wip1}^{-/-}$) reduces the level of p53-inactivation in Tax expressing cells compared to counterpart cells that expresses both Wip1 and Tax (i.e. $\operatorname{Tax}^{+} \mathrm{Wipl}^{+/+}$); this reduced inactivation of p53 could explain the increased tumor-free survival observed in the Tax ${ }^{+} \mathrm{Wip1}^{-/-}$ over the $\mathrm{Tax}^{+} \mathrm{Wipl}^{+/+}$mice.

Tax expression does not increase Wip 1 transcription

Figure 4B shows that when Tax and Wip1 are expressed together overall in vivo transforming potential is increased. Tax is known to activate or repress the transcription of various genes [75-80]; thus a possibility is that Tax expression affects Wip1 transcription. To address this possibility, RNA was isolated from Taxexpressing HTLV-1-transformed MT2, MT4, C8166 cells and compared to RNAs from HTLV-1-negative $\mathrm{CD}^{+}{ }^{+} \mathrm{T}$-cell lines, CEM, Jurkat and $\mathrm{H} 9$; specific transcripts were quantified by real-time RT-PCR (Figure 5A). The real-time RT-PCR results showed no correlation between Tax expression and Wip1 expression in these cells. To check in a different way that Tax has no effect on Wip1 transcription, we transiently transfected p53 ${ }^{-/}$HCT116 (Figure 5B), p53 ${ }^{+/+}$HCT116 (Figure 5C), or HeLa cells (Figure 5D) with various amounts of a Tax expression plasmid and measured Wip1 mRNA. p53 HCT116 and p53 ${ }^{+/+}$HCT116 cells [81] have been commonly used to study p53 function. In these cells, we observed no statistically significant change in Wip1 mRNA upon Tax expression. We also transfected MEFs and HCT-116 cells with a Tax expression plasmid and immunostained the cells for Tax and Wip1 proteins. Based on visualization by confocal microscopy, no difference in 
A
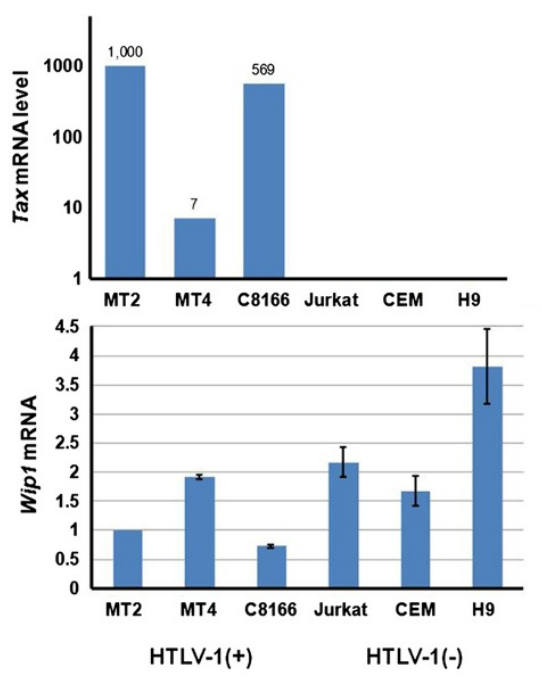

B

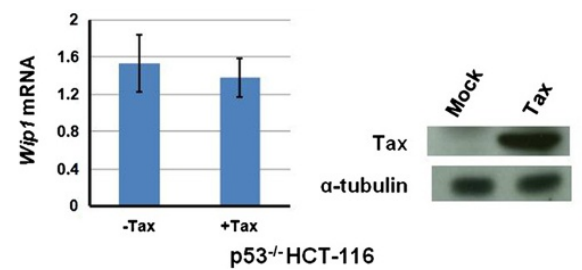

C

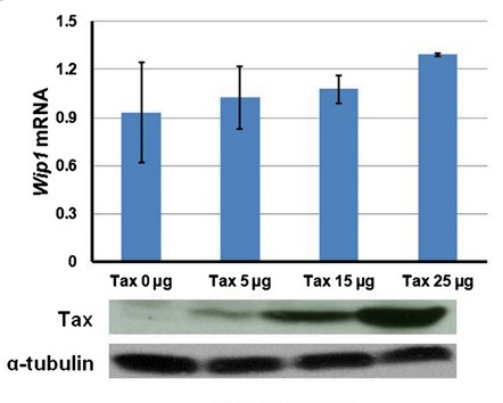

p $53^{+/+}$HCT -116

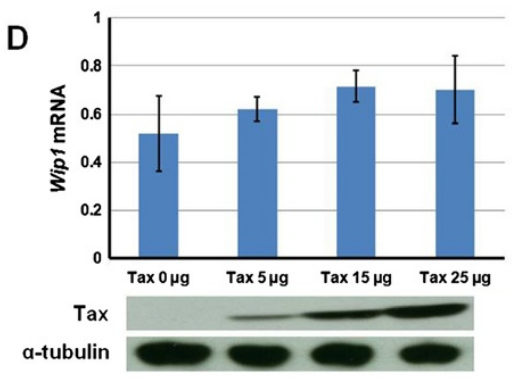

HeLa

Figure 5 Analysis of Wip1 mRNA expression in Tax-expressing and Tax-non-expressing cells. (A) Total RNAs from HTLV-1-transformed MT-2, MT4, C8166 T-cell lines and HTLV-1-negative CD4 ${ }^{+}$control T-cell lines (Jurkat, CEM, and H9) were extracted and reverse transcribed. The CDNAs were used for real-time RT-PCR analyses of Wip1, Tax, and GAPDH (internal standard) transcripts. The mRNA relative expression levels of Wip1 and Tax mRNA were determined and normalized as multiples of the GAPDH mRNA. The columns represent the average results from 3 experiments; the error bars are mean errors. (B) Real-time RT-PCR analyses of Wip1 and GAPDH (internal control) transcripts were performed in p53 $3^{-/-}$HCT116, (C) p53 $3^{+/+}$HCT116 and (D) HeLa cells after transfection with a control vector or a Tax-expression vector. To detect Tax protein, immunoblots were stained using Tax and a-tubulin specific monoclonal antibodies. Tubulin was used as a loading control.

Wip1 signal intensity was seen in Tax-expressing cells versus Tax-negative cells (Figure 6A and Additional file 2: Figure S2A). These findings demonstrate that Tax expression does not change ambient Wip1 protein level and agree with the RNA measurement results that Tax expression does not alter Wip1 mRNA expression (Figure 5).

In our immunostainings, we did note that Tax and Wip1 colocalize in the nucleus (Figure 6A and Additional file 2: Figure S2A). Moreover, additional immunostainings also show that Wip1 and p53 colocalize in the nucleus (Figure 6B and Additional file 2: Figure S2B). Thus, conceivably, Tax, p53, and Wip1 interaction occurs through intranuclear contacts. Currently, we do not have sufficient data to fully understand whether the colocalization of Tax, Wip1, and p53 manifests in direct protein-protein interactions or the proteins interact through bridging by additional factors. Experiments are in progress to define better these mechanistic interactions.

\section{Discussion}

Colloquially known as the guardian of the genome, p53 is an important player in cancer biology, as exemplified by its ubiquitous loss of function in cancers. Thus, approximately $50 \%$ of human cancers are genetically mutated in p53 [29,82-85], and the other $50 \%$ show attenuated or abrogated p53 activity through means other than mutation [86]. In the case of ATLL, the frequency of p53 gene deletion and mutation is lower than in many other types of cancers and has been reported to approximate 15\% [54]. Indeed, our own anecdotal findings are consistent with this low prevalence; in a recent survey of 7 primary ATLL cells, we found no evidence for any of the 11 most frequent p53 somatic gene mutations that have been described for lymphoid neoplasms (Zane, data not shown).

Cancers that retain wild-type p53 gene, nevertheless, can have attenuated p53 activity via other mechanisms. For example, Mdm2, an E3 ubiquitin ligase that promotes p53 degradation, is a major negative regulator of p53 [87-89]. Another example of negative regulation arises from the Twist 1 protein. Twist 1 accumulates in sarcomas that are genotypically p53 wild-type; it dysregulates p53 phosphorylation promoting its degradation [90]. Additional examples come from DNA tumor 


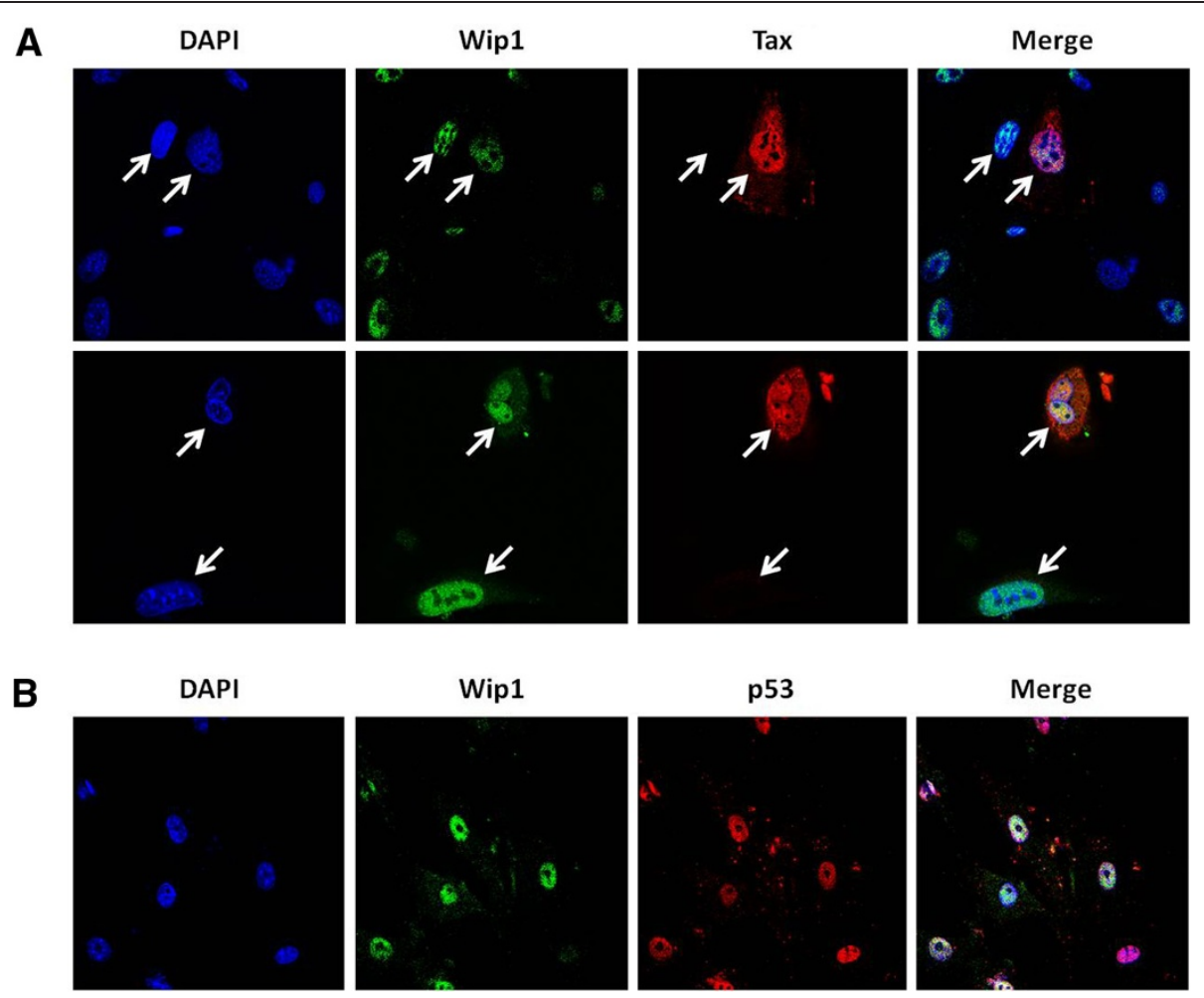

Figure 6 Confocal analyses of p53, Wip1 and Tax in MEF cells. (A) Analysis of cell endogenous Wip1 and Tax expression and localization by immunofluorescence staining in MEF cells transfected with a Tax expression plasmid for 48 hours. Cells were stained with anti-Tax (red) and anti-Wip1 (green) antibodies. The nuclei were stained with DAPI (blue). Arrows point to cell that expresses Tax (red) and a neighboring cell that does not express Tax. The same two cells are shown to express equal intensities of Wip1 (green). DAPI (blue) stains cellular nuclei. (B) The colocalization of cell endogenous p53 and Wip1 in MEF cells. Cells were stained with anti-p53 (red) or anti-Wip1 (green) antibodies, and DAPI was used to stain nuclei (blue).

viruses; some encode proteins that repress p53 activity. Hence, SV40 large T-antigen stabilizes, but inactivates, p53; adenovirus E1B-55-kDa protein, and the E6 oncoprotein of human papilloma virus (HPV) types 16 and 18 target p53 for ubiquitinylation and degradation [91-93]. In the case of HTLV-1, our work here reaffirms previous findings that Tax indeed attenuates p53's transcriptional activity in cultured cells (Figure 3). However, a perhaps more important implication to arise from our study is that we compare for the first time the impact of Tax inactivation of p53 versus p53 inactivation by genetic mutation for their relative contributions to in vivo tumorigenesis in mice. To date, it generally has been believed that Tax stringently inactivates p53 activity reducing the need for ATL cells to acquire p53 inactivating mutations. Our results are, however, incongruent with this notion. Thus, we found that Tax induces tumorigenesis in mice much more robustly in a $p 53^{-/-}$ setting than in a $p 53^{+/+}$context (Figure 2A), suggesting that Tax inhibition of p53 in the latter context is significantly less complete than p53 inactivation via gene mutation. Our findings differ somewhat from those reported by Portis et al. [94]. The differences may be due to variances in the mouse numbers, the mouse strains, and the criteria used to determine tumor-free survival and when euthanasias of mice are performed. To date, in the published literature, only cross-sectional findings are associated between p53 genetic mutations and human ATLLs [54]. These findings do not offer clarity on when p53 mutations occurred relative to HTLV-1 infection, Tax expression, and the onset of transformation of ATLL cells. Our results in mice provide prospective analyses of the contribution of a $p 53^{-/-}$genotype to the initiation of in vivo tumorigenesis by Tax. Accordingly, extrapolating our mouse findings to humans suggests that early loss of p53 through a $p 53^{-/-}$genetic mutation in cells infected by HTLV-1 foretells a worse prognosis compared to a corresponding infection in a counterpart $p 53^{+/+}$ setting.

In our investigation of p53 inactivation, we report for the first time a contributory role by Wip1 in Taxtumorigenesis. Our insight into the role of Wip1 arose from the observation that loss of Wip1 (i.e. Wip1 $1^{-/}$) significantly reduced the frequency of tumor development in Tax transgenic mice (Figure 4B). We linked this observation to a Wip1-mediated p53 effect because we 
found that $W_{i p 1^{-/-}}$MEFs have significantly increased p53 activity over their Wip1 $1^{+/+}$counterparts. Thus, a parsimonious interpretation of the collective findings is that loss of Wip1 phosphatase (i.e. $\mathrm{Wip1}^{-/-}$) increases cell endogenous p53 activity (Figures 3D and E), and this increase in $\mathrm{p} 53$ function reduces Tax-tumorigenicity in $\mathrm{Tax}^{+} \mathrm{Wip1}^{-/-}$mice (Figure 4B). Hence, the magnitude of p53 activity is important in regulating the extent of in vivo Tax tumorigenesis, and this view is further consistent with the tumor-free survival results comparing $\operatorname{Tax}^{+} p 53^{+/+}$and $\operatorname{Tax}^{+} p 53^{-/-}$mice (Figure 1).

The potential value of inhibiting Wip1 in moderating cancer progression is not only limited to Tax-induced tumors because a Wip1 effect has also been suggested in mammary gland tumors [95], lymphomas [96], colorectal cancers [97], and other spontaneous tumors [98]. Going forward further clarification is needed to understand whether Wip1's effect on many cancers and its impact on Tax-driven tumor formation are primarily due to its effect on p53 signaling or may also arise from its known effects on other pathways, such as ARF, ATM, and p38 MAPK signaling $[96,99]$. Studies that compare the in vivo tumorigenesis frequencies seen in $\operatorname{Tax}^{+} \mathrm{Wip1}^{-/-} p 53^{-/-}$

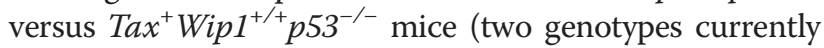
being bred in our laboratory) may help to address whether Wip1 has important substrates other than p53 that contribute to Tax-mediated transformation. In other models of carcinogenesis, it has been shown that the singular over-expression of Wip1 is insufficient to initiate oncogenesis [100] and that Wip1 mostly promotes tumors by cooperating with known oncogenes [100]. Nevertheless, amplification of the Wip1 gene has been described for numerous human primary tumors [101-112], with virtually all such tumors being genetically p53 wild-type $[71,72,113]$. Based on this observation, one wonders if the low selective pressure for p53 mutations in ATLL could be due to Wip1 gene amplification in these cells. To our knowledge, this important question has not yet been investigated in ATLLs.

\section{Conclusions}

In summary, despite much progress in HTLV-1 research over the past three decades [114], a salient finding to emerge from this work is the new identification of Wip1 as a cooperating cellular co-factor of Tax in p53inactivation and in vivo tumorigenesis. Currently, our confocal imaging results suggest a colocalization between Tax, Wip1, and p53 within the nucleus (Figure 6 and Additional file 2: Figure S2), but we still lack sufficient data to decipher mechanistically how Tax and Wip1 cooperate to inactivate p53. Amongst several plausible mechanisms, we remain unable to conclude whether Tax can increase Wip1 dephosphorylation of p53 and/or MDM2, a major inhibitor of p53 that has been reported to also be a target of Wip1 [99]. Nonetheless, the functional delineation here of a contribution by Wip1 to Tax tumorigenesis (Figure 4B) does raise the possibility that future uses of small molecule Wip1 phosphatase-inhibitors [115] may benefit ATLL treatment.

\section{Methods}

\section{Animals and genotyping}

The Tax and Wip1+/- transgenic mice were previously described $[15,74]$. The p53-mutant mice were purchased from the Jackson lab (strain:B6.129S2-Trp53tm1Tyj/J) [68]. The Wip1 and p53 knockout and Tax transgenic mice were all generated in C57BL/6 × 129/sv backgrounds $[15,68,74]$. Genotypes of the mice were determined by polymerase chain reactions (PCRs) using primers: Tax (Tax-F-7511-7530: $5^{\prime}$-tcggctcagctctacagttc-3'; Tax-R-80448025: $5^{\prime}$-tgagggttgagtggaacgga- $3^{\prime}$ ), p53 (wt: $5^{\prime}$-acagcgtggtgg taccttat- $3^{\prime}$, mutant: $5^{\prime}$-ctatcaggacatagcgttgg- $3^{\prime}$ and common: $5^{\prime}$-tatactcagagccggcct- $3^{\prime}$ ) and Wip1 (Wip1 Exon4 F: $5^{\prime}$-gtggagctatgatttcttcagtgg-3'; Wip1 Exon4 R: $5^{\prime}$-g atacgacacaagacaaacctcc-3'; Wip1 intron 3: $5^{\prime}$-acaagcttg cagggctgtttgtgg- ${ }^{\prime}$; PGK promoter: $5^{\prime}$-cttccagctctgagc ccagaaagc- $\left.3^{\prime}\right)$. Experimental research on mice follows NIH approved animal study protocols and guidelines.

\section{Analyses of pathologies}

Mice were necropsied and examined by mouse pathologists. All of the internal organs (spleen, liver, pancreas, kidney, stomach, intestine, lung, heart, brain, lymph node, thyroid gland) were fixed, paraffin embedded, sectioned and stained with $H \& E$ for analyses. Tissues that were found to be grossly abnormal at time of necropsy were multiply sectioned and stained by H\&E (hematoxylin and eosin) for microscopic histological analyses.

\section{Cells and reagents}

Human cervical cancer cell line HeLa and human colorectal carcinoma cell lines $\mathrm{p} 53^{+/+} \mathrm{HCT} 116$ and $\mathrm{p} 53^{-/-} \mathrm{HCT} 116$ [81] were cultured in Dulbecco's modified Eagle's medium containing $10 \%$ fetal bovine serum (FBS) and antibiotics. Human T cell lines MT2, MT4, C8166, Jurkat, A301, CEM, and H9 were maintained in RPMI 1640 with 10\% FBS.

\section{Antibodies}

Mouse monoclonal anti-Tax (NIH AIDS Research and Reference Reagent Program) was used to detect Tax protein in immunoblotting and by confocal microscopy. Anti-Flag monoclonal antibody (M2; mouse; Sigma), antiWip1 polyclonal antibody (rabbit; Santa Cruz), anti-p53 
monoclonal antibody (mouse; Cell Signaling) and antitubulin monoclonal antibody (DM1A; mouse; Sigma) were purchased.

\section{Plasmids and transfections}

pG13-Luc, p53 (human wild type) (gifts from B. Vogelstein) and Wip1 (gift from L.A. Donehower) expression plasmids were previously described $[73,116,117]$. HeLa or $\mathrm{p} 53^{+/+}$ HCT116 or $\mathrm{p} 53^{-/-}$HCT116 cells were seeded into twelvewell tissue culture plates for the luciferase assays and into $10 \mathrm{~cm}$-dishes for Tax transfections. Transfections were performed $24 \mathrm{~h}$ later, using Lipofectamine and Plus reagent (Invitrogen) as described by the manufacturer. At $24 \mathrm{~h}$ after transfection of the reporters, cell lysates were subjected to luciferase assay. Total amounts of DNA to be transfected were adjusted by the addition of empty vectors. To detect luciferase and $\beta-G a l$ activity, luciferase substrate (Promega) and the Galacto-Star assay system (Applied Biosystems) were used. Relative values of luciferase activity were calculated using $\beta-G a l$ activity as an internal control for transfection.

\section{Real-time PCR}

For real-time quantitative reverse transcriptase-polymerase chain reaction (qRTPCR), total cellular RNA from samples was isolated using TriZol reagent according to the manufacturer's instructions (Invitrogen Life technologies). Before reverse transcription, RNA was treated by DNase (Invitrogen) to prevent DNA contamination. First-strand cDNA was synthesized from $1 \mu \mathrm{g}$ RNA using oligodT and Superscript III reverse transcriptase (Invitrogen). RNA concentration and purity were determined by UV spectrophotometry (nanodrop). The primer pairs were designed using the Universal Probe Library website (Roche diagnostics) (Wip1-L hs: $5^{\prime}$-cccatgttctacaccaccagt-3'; Wip1-R hs: $5^{\prime}$-tggtccttagaatt cacccttg-3'; p53-L hs: $5^{\prime}$-ccccagccaaagaagaaac- $3^{\prime}$; p53-R hs: $5^{\prime}$-aacatctcgaagcgctcac-3'; p21-L hs: $5^{\prime}$-cgaagtcagttcct tgtggag- $3^{\prime}$; p21-R hs: $5^{\prime}$-catgggttctgacggacat- $\left.3^{\prime}\right)$. The primers of each pair were located in different exons to avoid genomic amplification. Primer and probe sequences to detect Tax in human T-cells [118] and Tax-SK43: $5^{\prime}$-cggata cccagtctacgtgt- $3^{\prime}$ and Tax-SK44: $5^{\prime}$-gagccgataacgcgtccatcg- $3^{\prime}$ to detect Tax in mouse spleens. GAPDH was used as the reference gene for he normalization of results (GAPDH-R: 5'-agtgggtgtcgctgttgaag-3'; GAPDH-F: 5' - tgg tatcgtggaaggactca-3'). PCRs were performed using iQSupermix (Bio-Rad) (for quantification of Tax cDNAs in human T-cells) and iQSYBR Green Supermix (for quantification of other cDNAs) on a CFX96 system (Bio-Rad). A large amount of cDNA was prepared from the MT2, C8166, and MT4 cell lines prior to the experiment. This cDNA was 10 fold-diluted, aliquoted and used as a calibrator for Tax and other RT-PCR runs, respectively. For relative quantification and normalization, the comparative Ct (or Eff-DDC) method was used [119].

\section{Immunofluorescence}

Cells were cultured on glass coverslips, and fixed in $4 \%$ paraformaldehyde at $24 \mathrm{~h}$ after transfection. After blocking of nonspecific reactions with $1 \%$ bovine serum albumin (BSA), cells were then incubated with the indicated primary antibodies, followed by a subsequent incubation with the secondary antibodies conjugated with Alexa Fluor 488 or 594 (Molecular Probes). DNA was counterstained with $0.1 \mu \mathrm{g} / \mathrm{ml}$ Hoechst 33342. Coverslips were mounted in Prolong Antifade (Molecular Probes), and cells were visualized with a Leica TCS SP2 confocal microscope.

\section{Statistical analyses}

The statistical analysis of tumor numbers, survival curves, and spleen weights were computed using the PRISM software (version 5.03).

\section{Additional files}

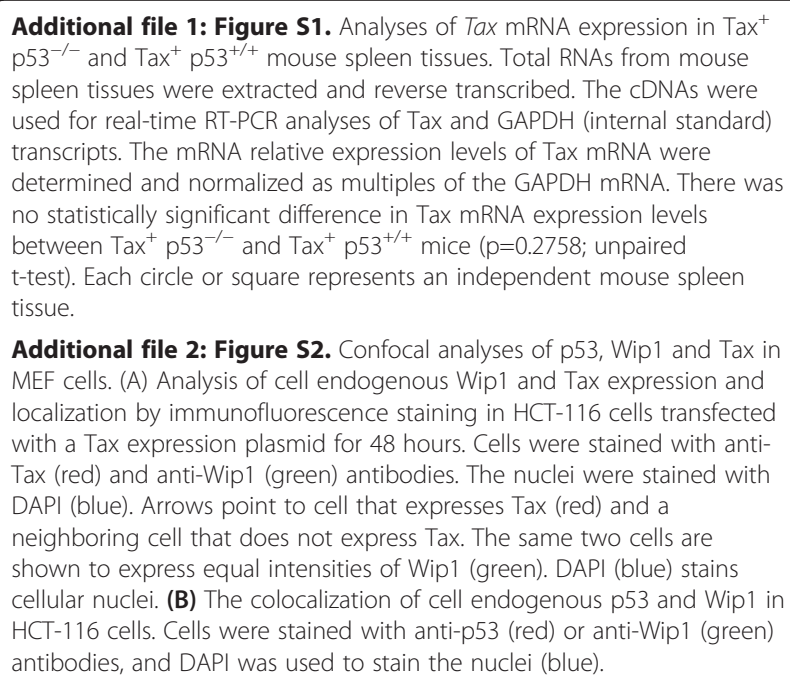

Additional file 2: Figure S2. Confocal analyses of p53, Wip1 and Tax in MEF cells. (A) Analysis of cell endogenous Wip1 and Tax expression and localization by immunofluorescence staining in HCT-116 cells transfected with a Tax expression plasmid for 48 hours. Cells were stained with antiTax (red) and anti-Wip1 (green) antibodies. The nuclei were stained with DAPI (blue). Arrows point to cell that expresses Tax (red) and a neighboring cell that does not express Tax. The same two cells are shown to express equal intensities of Wip1 (green). DAPI (blue) stains cellular nuclei. (B) The colocalization of cell endogenous p53 and Wip1 in HCT-116 cells. Cells were stained with anti-p53 (red) or anti-Wip1 (green) antibodies, and DAPI was used to stain the nuclei (blue).

\section{Competing interests}

The authors declare that they have no competing interests.

\section{Authors' contributions}

LZ designed and performed the work, analyzed the data and wrote the paper. YJ started mouse breedings and genotypings. YM performed some genotypings. WY, SWT and CYC contributed reagents and technical advice for the work and edited the paper. LR and XL provided, respectively, Tax and Wip1 mice and participated in discussions. KTJ conceived of the study and supervised the work and wrote the paper. All authors read and approved the final manuscript.

\section{Acknowledgement}

This work was supported by intramural NIAID funding. XL was supported by $\mathrm{NIH}$ grant R01CA136549. We thank members of the Jeang laboratory for critical readings of the manuscript; Qingpin Liu for her help with mouse tissues and Melissa Foster and Ryan Hamilton for caring of the mice. 


\section{Author details}

${ }^{1}$ Molecular Virology Section, Laboratory of Molecular Microbiology, the National Institutes of Allergy and Infectious Diseases, the National Institutes of Health, Bethesda, Maryland 20892-0460, USA. 'Laboratory of Virus Control, Institute for Virus Research, Kyoto University, Kyoto, Japan. 3Department of Medicine, Washington University School of Medicine, Saint-Louis, Missouri, USA. ${ }^{4}$ Department of Cancer Biology, the University of Texas MD Anderson Cancer Center, Houston, Texas, USA.

Received: 16 October 2012 Accepted: 15 December 2012

Published: 21 December 2012

\section{References}

1. Proietti FA, Carneiro-Proietti AB, Catalan-Soares BC, Murphy EL: Global epidemiology of HTLV-I infection and associated diseases. Oncogene 2005, 24(39):6058-6068.

2. Poiesz BJ, Ruscetti FW, Gazdar AF, Bunn PA, Minna JD, Gallo RC: Detection and isolation of type $C$ retrovirus particles from fresh and cultured lymphocytes of a patient with cutaneous T-cell lymphoma. Proc Natl Acad Sci U S A 1980, 77(12):7415-7419.

3. Hinuma Y, Nagata K, Hanaoka M, Nakai M, Matsumoto T, Kinoshita Kl, Shirakawa S, Miyoshi l: Adult T-cell leukemia: antigen in an ATL cell line and detection of antibodies to the antigen in human sera. Proc Natl Acad Sci U S A 1981, 78(10):6476-6480.

4. Miyoshi I, Kubonishi I, Yoshimoto S, Akagi T, Ohtsuki Y, Shiraishi Y, Nagata K, Hinuma $Y$ : Type $C$ virus particles in a cord T-cell line derived by co-cultivating normal human cord leukocytes and human leukaemic T cells. Nature 1981, 294(5843):770-771.

5. Yoshida M, Miyoshi I, Hinuma Y: Isolation and characterization of retrovirus from cell lines of human adult T-cell leukemia and its implication in the disease. Proc Natl Acad Sci U S A 1982, 79(6):2031-2035.

6. Watanabe T, Seiki M, Yoshida M: Retrovirus terminology. Science 1983, 222(4629):1178

7. Gallo RC: History of the discoveries of the first human retroviruses: HTLV-1 and HTLV-2. Oncogene 2005, 24(39):5926-5930.

8. Goncalves DU, Proietti FA, Barbosa-Stancioli EF, Martins ML, Ribas JG, Martins-Filho OA, Teixeira-Carvalho A, Peruhype-Magalhaes $V$, Carneiro-Proietti AB: HTLV-1-associated myelopathy/tropical spastic paraparesis (HAM/TSP) inflammatory network. Inflamm Allergy Drug Targets 2008, 7(2):98-107.

9. Gessain A, Mahieux R: Tropical spastic paraparesis and HTLV-1 associated myelopathy: clinical, epidemiological, virological and therapeutic aspects. Rev Neurol (Paris) 2012, 168(3):257-269.

10. Tanaka A, Takahashi C, Yamaoka S, Nosaka T, Maki M, Hatanaka M: Oncogenic transformation by the tax gene of human T-cell leukemia virus type I in vitro. Proc Natl Acad Sci U S A 1990, 87(3):1071-1075.

11. Zane L, Yasunaga J, Kinjo T, de Melo G, Jeang KT: Transformation of human embryonic stem cells by HTLV-1 Tax. Retrovirology 2011 8(Suppl 1):A164

12. Grassmann R, Berchtold S, Radant I, Alt M, Fleckenstein B, Sodroski JG, Haseltine WA, Ramstedt U: Role of human T-cell leukemia virus type $1 \mathrm{X}$ region proteins in immortalization of primary human lymphocytes in culture. J Virol 1992, 66(7):4570-4575.

13. Rosin O, Koch C, Schmitt I, Semmes OJ, Jeang KT, Grassmann R: A human T-cell leukemia virus Tax variant incapable of activating NF-kappaB retains its immortalizing potential for primary T-lymphocytes. J Biol Chem 1998, 273(12):6698-6703.

14. Nerenberg M, Hinrichs SH, Reynolds RK, Khoury G, Jay G: The tat gene of human T-lymphotropic virus type 1 induces mesenchymal tumors in transgenic mice. Science 1987, 237(4820):1324-1329

15. Grossman WJ, Kimata JT, Wong FH, Zutter M, Ley TJ, Ratner L: Development of leukemia in mice transgenic for the tax gene of human T-cell leukemia virus type I. Proc Natl Acad Sci U S A 1995, 92(4):1057-1061.

16. Hasegawa H, Sawa H, Lewis MJ, Orba Y, Sheehy N, Yamamoto Y, Ichinohe T, Tsunetsugu-Yokota $Y$, Katano H, Takahashi H, et al: Thymus-derived leukemia-lymphoma in mice transgenic for the Tax gene of human T-lymphotropic virus type I. Nat Med 2006, 12(4):466-472.

17. Ohsugi T, Kumasaka T, Okada S, Urano T: The Tax protein of HTLV-1 promotes oncogenesis in not only immature T cells but also mature T cells. Nat Med 2007, 13(5):527-528.
18. Grassmann R, Aboud M, Jeang KT: Molecular mechanisms of cellular transformation by HTLV-1 Tax. Oncogene 2005, 24(39):5976-5985.

19. Matsuoka $M$, Jeang KT: Human T-cell leukemia virus type 1 (HTLV-1) and leukemic transformation: viral infectivity, Tax, HBZ and therapy. Oncogene 2011, 30(12):1379-1389.

20. Zane L, Sibon D, Jeannin L, Zandecki M, Delfau-Larue MH, Gessain A, Gout $O$, Pinatel C, Lancon A, Mortreux F, et al: Tax gene expression and cell cycling but not cell death are selected during HTLV-1 infection in vivo. Retrovirology 2010, 7:17

21. Jeang KT, Boros I, Brady J, Radonovich M, Khoury G: Characterization of cellular factors that interact with the human T-cell leukemia virus type p40x-responsive 21-base-pair sequence. J Virol 1988, 62(12):4499-4509.

22. Goren I, Semmes OJ, Jeang KT, Moelling K: The amino terminus of Tax is required for interaction with the cyclic AMP response element binding protein. J Virol 1995, 69(9):5806-5811.

23. Tie F, Adya N, Greene WC, Giam CZ: Interaction of the human T-lymphotropic virus type 1 Tax dimer with CREB and the viral 21-base-pair repeat. J Virol 1996, 70(12):8368-8374.

24. Harrod R, Tang Y, Nicot C, Lu HS, Vassilev A, Nakatani Y, Giam CZ: An exposed KID-like domain in human T-cell lymphotropic virus type 1 Tax is responsible for the recruitment of coactivators CBP/p300. Mol Cell Biol 1998, 18(9):5052-5061.

25. Harhaj EW, Sun SC: IKKgamma serves as a docking subunit of the IkappaB kinase (IKK) and mediates interaction of IKK with the human T-cell leukemia virus Tax protein. J Biol Chem 1999, 274(33):22911-22914.

26. Xiao G, Cvijic ME, Fong A, Harhaj EW, Uhlik MT, Waterfield M, Sun SC: Retroviral oncoprotein Tax induces processing of NF-kappaB2/p100 in T cells: evidence for the involvement of IKKalpha. EMBO J 2001 20(23):6805-6815

27. Iha H, Kibler KV, Yedavalli VR, Peloponese JM, Haller K, Miyazato A, Kasai T, Jeang KT: Segregation of NF-kappaB activation through NEMO/ IKKgamma by Tax and TNFalpha: implications for stimulus-specific interruption of oncogenic signaling. Oncogene 2003, 22(55):8912-8923.

28. Qu Z, Xiao G: Human T-cell lymphotropic virus: a model of NF-kappaBassociated tumorigenesis. Viruses 2011, 3(6):714-749.

29. Fu DX, Kuo YL, Liu BY, Jeang KT, Giam CZ: Human T-lymphotropic virus type I tax activates I-kappa B kinase by inhibiting I-kappa B kinase-associated serine/threonine protein phosphatase 2A. J Biol Chem 2003, 278(3):1487-1493.

30. Iwanaga R, Ohtani K, Hayashi T, Nakamura M: Molecular mechanism of cell cycle progression induced by the oncogene product Tax of human T-cell leukemia virus type I. Oncogene 2001, 20(17):2055-2067.

31. Haller K, Wu Y, Derow E, Schmitt I, Jeang KT, Grassmann R: Physical interaction of human T-cell leukemia virus type 1 Tax with cyclin-dependent kinase 4 stimulates the phosphorylation of retinoblastoma protein. Mol Cell Biol 2002, 22(10):3327-3338.

32. Fraedrich $\mathrm{K}$, Muller B, Grassmann R: The HTLV-1 Tax protein binding domain of cyclin-dependent kinase 4 (CDK4) includes the regulatory PSTAIRE helix. Retrovirology 2005, 2:54.

33. Neuveut C, Low KG, Maldarelli F, Schmitt I, Majone F, Grassmann R, Jeang $K T$ : Human T-cell leukemia virus type 1 Tax and cell cycle progression: role of cyclin D-cdk and p110Rb. Mol Cell Biol 1998, 18(6):3620-3632.

34. Jeong SJ, Dasgupta A, Jung KJ, Um JH, Burke A, Park HU, Brady JN: PI3K/ AKT inhibition induces caspase-dependent apoptosis in HTLV-1transformed cells. Virology 2008, 370(2):264-272.

35. Liu Y, Wang Y, Yamakuchi M, Masuda S, Tokioka T, Yamaoka S, Maruyama I, Kitajima I: Phosphoinositide-3 kinase-PKB/Akt pathway activation is involved in fibroblast Rat-1 transformation by human T-cell leukemia virus type I tax. Oncogene 2001, 20(20):2514-2526.

36. Peloponese JM Jr, Jeang KT: Role for Akt/protein kinase B and activator protein-1 in cellular proliferation induced by the human T-cell leukemia virus type 1 tax oncoprotein. J Biol Chem 2006, 281(13):8927-8938.

37. Majone F, Semmes OJ, Jeang KT: Induction of micronuclei by HTLV-I Tax: a cellular assay for function. Virology 1993, 193(1):456-459.

38. Semmes OJ, Majone F, Cantemir C, Turchetto L, Hjelle B, Jeang KT: HTLV-I and HTLV-II Tax: differences in induction of micronuclei in cells and transcriptional activation of viral LTRs. Virology 1996, 217(1):373-379.

39. Kinjo T, Ham-Terhune J, Peloponese JM Jr, Jeang KT: Induction of reactive oxygen species by human T-cell leukemia virus type 1 tax correlates with DNA damage and expression of cellular senescence marker. J Virol 2010, 84(10):5431-5437. 
40. Majone F, Jeang KT: Unstabilized DNA breaks in HTLV-1 Tax expressing cells correlate with functional targeting of Ku80, not PKcs, XRCC4, or H2AX. Cell Biosci 2012, 2(1):15.

41. Durkin SS, Guo X, Fryrear KA, Mihaylova VT, Gupta SK, Belgnaoui SM, Haoudi A, Kupfer GM, Semmes OJ: HTLV-1 Tax oncoprotein subverts the cellular DNA damage response via binding to DNA-dependent protein kinase. J Biol Chem 2008, 283(52):36311-36320.

42. Gatza ML, Dayaram T, Marriott SJ: Ubiquitination of HTLV-I Tax in response to DNA damage regulates nuclear complex formation and nuclear export. Retrovirology 2007, 4:95

43. Hanahan D, Weinberg RA: The hallmarks of cancer. Cell 2000, 100(1):57-70.

44. Hanahan D, Weinberg RA: Hallmarks of cancer: the next generation. Cell 2011, 144(5):646-674.

45. Jin DY, Spencer F, Jeang KT: Human T cell leukemia virus type 1 oncoprotein Tax targets the human mitotic checkpoint protein MAD1. Cell 1998, 93(1):81-91.

46. Yasunaga J, Jeang KT: Viral transformation and aneuploidy. Environ Mol Mutagen 2009, 50(8):733-740.

47. Vousden KH, Lu X: Live or let die: the cell's response to p53. Nat Rev Cancer 2002, 2(8):594-604.

48. Zenz T, Benner A, Dohner H, Stilgenbauer S: Chronic lymphocytic leukemia and treatment resistance in cancer: the role of the p53 pathway. Cell Cycle 2008, 7(24):3810-3814.

49. Freed-Pastor WA, Prives C: Mutant p53: one name, many proteins. Genes Dev 2012, 26(12):1268-1286.

50. Xu-Monette ZY, Medeiros L, Li Y, Orlowski RZ, Andreeff M, Bueso-Ramos CE, Greiner TC, McDonnell TJ, Young KH: Dysfunction of the TP53 tumor suppressor gene in lymphoid malignancies. Blood 2012, 119(16):3668-3683.

51. Toyooka S, Tsuda T, Gazdar AF: The TP53 gene, tobacco exposure, and lung cancer. Hum Mutat 2003, 21(3):229-239.

52. lacopetta B: TP53 mutation in colorectal cancer. Hum Mutat 2003, 21(3):271-276.

53. Hatta Y, Koeffler HP: Role of tumor suppressor genes in the development of adult T cell leukemia/lymphoma (ATLL). Leukemia 2002, 16(6):1069-1085

54. Tawara M, Hogerzeil SJ, Yamada Y, Takasaki Y, Soda H, Hasegawa H, Murata K, Ikeda S, Imaizumi Y, Sugahara K, et al: Impact of p53 aberration on the progression of Adult T-cell Leukemia/Lymphoma. Cancer Lett 2006, 234(2):249-255.

55. Tabakin-Fix Y, Azran I, Schavinky-Khrapunsky Y, Levy O, Aboud M: Functional inactivation of p53 by human T-cell leukemia virus type 1 Tax protein: mechanisms and clinical implications. Carcinogenesis 2006, 27(4):673-681.

56. Nagai H, Kinoshita T, Imamura J, Murakami Y, Hayashi K, Mukai K, Ikeda S, Tobinai K, Saito H, Shimoyama M, et al: Genetic alteration of p53 in some patients with adult T-cell leukemia. Jpn J Cancer Res 1991, 82(12):1421-1427.

57. Sakashita A, Hattori T, Miller CW, Suzushima H, Asou N, Takatsuki K, Koeffler HP: Mutations of the p53 gene in adult T-cell leukemia. Blood 1992, 79(2):477-480

58. Reid RL, Lindholm PF, Mireskandari A, Dittmer J, Brady JN: Stabilization of wild-type p53 in human T-lymphocytes transformed by HTLV-I. Oncogene 1993, 8(11):3029-3036.

59. Pise-Masison CA, Choi KS, Radonovich M, Dittmer J, Kim SJ, Brady JN: Inhibition of p53 transactivation function by the human T-cell lymphotropic virus type 1 Tax protein. J Virol 1998, 72(2):1165-1170.

60. Pise-Masison CA, Radonovich M, Sakaguchi K, Appella E, Brady JN: Phosphorylation of p53: a novel pathway for p53 inactivation in human T-cell lymphotropic virus type 1-transformed cells. J Virol 1998, 72(8):6348-6355

61. Akagi T, Ono H, Tsuchida N, Shimotohno K: Aberrant expression and function of p53 in T-cells immortalized by HTLV-I Tax1. FEBS Lett 1997 406(3):263-266.

62. Ariumi Y, Kaida A, Lin JY, Hirota M, Masui O, Yamaoka S, Taya Y, Shimotohno K: HTLV-1 tax oncoprotein represses the p53-mediated trans-activation function through coactivator CBP sequestration. Oncogene 2000, 19(12):1491-1499.

63. Pise-Masison CA, Mahieux R, Radonovich M, Jiang H, Brady JN: Human T-lymphotropic virus type I Tax protein utilizes distinct pathways for p53 inhibition that are cell type-dependent. J Biol Chem 2001, 276(1):200-205.
64. Van PL, Yim KW, Jin DY, Dapolito G, Kurimasa A, Jeang KT: Genetic evidence of a role for ATM in functional interaction between human T-cell leukemia virus type 1 Tax and p53. J Virol 2001, 75(1):396-407.

65. Miyazato A, Sheleg S, Iha H, Li Y, Jeang KT: Evidence for NF-kappaB- and CBP-independent repression of p53's transcriptional activity by human T-cell leukemia virus type 1 Tax in mouse embryo and primary human fibroblasts. J Virol 2005, 79(14):9346-9350.

66. Pise-Masison CA, Mahieux R, Jiang H, Ashcroft M, Radonovich M, Duvall J, Guillerm C, Brady JN: Inactivation of p53 by human T-cell lymphotropic virus type 1 Tax requires activation of the NF-kappaB pathway and is dependent on p53 phosphorylation. Mol Cell Biol 2000, 20(10):3377-3386.

67. Jeong SJ, Radonovich M, Brady JN, Pise-Masison CA: HTLV-I Tax induces a novel interaction between p65/RelA and p53 that results in inhibition of p53 transcriptional activity. Blood 2004, 104(5):1490-1497.

68. Jacks T, Remington $L$, Williams BO, Schmitt EM, Halachmi S, Bronson RT, Weinberg RA: Tumor spectrum analysis in p53-mutant mice. Curr Biol 1994, 4(1):1-7.

69. Chi YH, Ward JM, Cheng LI, Yasunaga J, Jeang KT: Spindle assembly checkpoint and p53 deficiencies cooperate for tumorigenesis in mice. Int J Cancer 2009, 124(6):1483-1489.

70. Fiscella M, Zhang H, Fan S, Sakaguchi K, Shen S, Mercer WE, Vande Woude GF, O'Connor PM, Appella E: Wip1, a novel human protein phosphatase that is induced in response to ionizing radiation in a p53-dependent manner. Proc Natl Acad Sci U S A 1997, 94(12):6048-6053.

71. Bulavin DV, Demidov ON, Saito S, Kauraniemi P, Phillips C, Amundson SA, Ambrosino C, Sauter G, Nebreda AR, Anderson CW, et al: Amplification of PPM1D in human tumors abrogates p53 tumor-suppressor activity. Nat Genet 2002, 31(2):210-215.

72. Yu E, Ahn YS, Jang SJ, Kim MJ, Yoon HS, Gong G, Choi J: Overexpression of the wip1 gene abrogates the p38 MAPK/p53/Wip1 pathway and silences p16 expression in human breast cancers. Breast Cancer Res Treat 2007, 101(3):269-278

73. el-Deiry WS, Kern SE, Pietenpol JA, Kinzler KW, Vogelstein B: Definition of a consensus binding site for p53. Nat Genet 1992, 1(1):45-49.

74. Choi J, Nannenga B, Demidov ON, Bulavin DV, Cooney A, Brayton C, Zhang Y, Mbawuike IN, Bradley A, Appella E, et al: Mice deficient for the wild-type p53-induced phosphatase gene (Wip1) exhibit defects in reproductive organs, immune function, and cell cycle control. Mol Cell Biol 2002, 22(4):1094-1105.

75. Waldele K, Silbermann K, Schneider G, Ruckes T, Cullen BR, Grassmann R: Requirement of the human T-cell leukemia virus (HTLV-1) tax-stimulated HIAP-1 gene for the survival of transformed lymphocytes. Blood 2006, 107(11):4491-4499.

76. Pichler K, Kattan T, Gentzsch J, Kress AK, Taylor GP, Bangham CR, Grassmann $R$ : Strong induction of $4-1 B B$, a growth and survival promoting costimulatory receptor, in HTLV-1-infected cultured and patients' T cells by the viral Tax oncoprotein. Blood 2008, 111(9):4741-4751.

77. Krueger A, Fas SC, Giaisi M, Bleumink M, Merling A, Stumpf C, Baumann S, Holtkotte D, Bosch V, Krammer PH, et al: HTLV-1 Tax protects against CD95-mediated apoptosis by induction of the cellular FLICE-inhibitory protein (c-FLIP). Blood 2006, 107(10):3933-3939.

78. Jeang KT, Widen SG, Semmes OJ, Wilson SH: HTLV-I trans-activator protein, tax, is a trans-repressor of the human beta-polymerase gene. Science 1990, 247(4946):1082-1084

79. Zhang J, Yamada O, Kida S, Matsushita Y, Yamaoka S, Chagan-Yasutan H, Hattori T: Identification of CD44 as a downstream target of noncanonical NF-kappaB pathway activated by human T-cell leukemia virus type 1-encoded Tax protein. Virology 2011, 413(2):244-252.

80. Zane L, Sibon D, Legras C, Lachuer J, Wierinckx A, Mehlen P, Delfau-Larue $\mathrm{MH}$, Gessain A, Gout O, Pinatel C, et al: Clonal expansion of HTLV-1 positive CD8+ cells relies on CIAP-2 but not on c-FLIP expression. Virology 2010, 407(2):341-351.

81. Bunz F, Dutriaux A, Lengauer C, Waldman T, Zhou S, Brown JP, Sedivy JM, Kinzler KW, Vogelstein B: Requirement for p53 and p21 to sustain G2 arrest after DNA damage. Science 1998, 282(5393):1497-1501.

82. Vogelstein B, Lane D, Levine AJ: Surfing the p53 network. Nature 2000, 408(6810):307-310.

83. Petitjean A, Achatz MI, Borresen-Dale AL, Hainaut P, Olivier M: TP53 mutations in human cancers: functional selection and impact on cancer prognosis and outcomes. Oncogene 2007, 26(15):2157-2165. 
84. Petitjean A, Mathe $E$, Kato S, Ishioka C, Tavtigian SV, Hainaut P, Olivier M: Impact of mutant p53 functional properties on TP53 mutation patterns and tumor phenotype: lessons from recent developments in the IARC TP53 database. Hum Mutat 2007, 28(6):622-629.

85. Levine AJ, Oren M: The first 30 years of p53: growing ever more complex. Nat Rev Cancer 2009, 9(10):749-758.

86. Polager S, Ginsberg D: p53 and E2f: partners in life and death. Nat ReV Cancer 2009, 9(10):738-748.

87. Poyurovsky MV, Prives C: Unleashing the power of p53: lessons from mice and men. Genes Dev 2006, 20(2):125-131.

88. Manfredi JJ: The Mdm2-p53 relationship evolves: Mdm2 swings both ways as an oncogene and a tumor suppressor. Genes Dev 2010, 24(15):1580-1589.

89. Marine JC, Lozano G: Mdm2-mediated ubiquitylation: 553 and beyond. Cell Death Differ 2010, 17(1):93-102.

90. Piccinin S, Tonin E, Sessa S, Demontis S, Rossi S, Pecciarini L, Zanatta L, Pivetta F, Grizzo A, Sonego M, et al: A "Twist box" Code of p53 Inactivation: Twist box:p53 Interaction Promotes p53 Degradation. Cancer Cell 2012, 22(3):404-415.

91. Levine AJ: The common mechanisms of transformation by the small DNA tumor viruses: the inactivation of tumor suppressor gene products: p53. Virology 2009, 384(2):285-293.

92. Atkin SJ, Griffin BE, Dilworth SM: Polyoma virus and simian virus 40 as cancer models: history and perspectives. Semin Cancer Biol 2009, 19(4):211-217

93. Gao P, Zheng J: Oncogenic virus-mediated cell fusion: new insights into initiation and progression of oncogenic viruses-related cancers. Cancer Lett 2011, 303(1):1-8.

94. Portis T, Grossman WJ, Harding JC, Hess JL, Ratner L: Analysis of p53 inactivation in a human T-cell leukemia virus type 1 Tax transgenic mouse model. J Virol 2001, 75(5):2185-2193.

95. Bulavin DV, Phillips C, Nannenga B, Timofeev O, Donehower LA, Anderson CW, Appella E, Fornace AJ Jr: Inactivation of the Wip1 phosphatase inhibits mammary tumorigenesis through p38 MAPK-mediated activation of the p16(Ink4a)-p19(Arf) pathway. Nat Genet 2004, 36(4):343-350

96. Shreeram S, Hee WK, Demidov ON, Kek C, Yamaguchi H, Fornace AJ Jr, Anderson CW, Appella E, Bulavin DV: Regulation of ATM/p53-dependent suppression of myc-induced lymphomas by Wip1 phosphatase. J Exp Med 2006, 203(13):2793-2799.

97. Demidov ON, Timofeev O, Lwin HN, Kek C, Appella E, Bulavin DV: Wip1 phosphatase regulates $\mathrm{p} 53$-dependent apoptosis of stem cells and tumorigenesis in the mouse intestine. Cell Stem Cell 2007, 1(2):180-190.

98. Nannenga B, Lu X, Dumble M, Van Maanen M, Nguyen TA, Sutton R, Kumar TR, Donehower LA: Augmented cancer resistance and DNA damage response phenotypes in PPM1D null mice. Mol Carcinog 2006, 45(8):594-604

99. Lu X, Nguyen TA, Moon SH, Darlington Y, Sommer M, Donehower LA: The type $2 \mathrm{C}$ phosphatase Wip1: an oncogenic regulator of tumor suppressor and DNA damage response pathways. Cancer Metastasis Rev 2008, 27(2):123-135.

100. Demidov ON, Kek C, Shreeram S, Timofeev O, Fornace AJ, Appella E, Bulavin DV: The role of the MKK6/p38 MAPK pathway in Wip1-dependent regulation of ErbB2-driven mammary gland tumorigenesis. Oncogene 2007, 26(17):2502-2506.

101. Li J, Yang Y, Peng Y, Austin RJ, van Eyndhoven WG, Nguyen KC, Gabriele T, McCurrach ME, Marks JR, Hoey T, et al: Oncogenic properties of PPM1D located within a breast cancer amplification epicenter at 17q23. Nat Genet 2002, 31(2):133-134.

102. Sinclair CS, Rowley M, Naderi A, Couch FJ: The 17q23 amplicon and breast cancer. Breast Cancer Res Treat 2003, 78(3):313-322.

103. Barlund M, Kuukasjarvi T, Syrjakoski K, Auvinen A, Kallioniemi A: Frequent amplification and overexpression of CCND1 in male breast cancer. Int $J$ Cancer 2004, 111(6):968-971.

104. Tan DS, Lambros MB, Rayter S, Natrajan R, Vatcheva R, Gao Q, Marchio C, Geyer FC, Savage K, Parry S, et al: PPM1D is a potential therapeutic target in ovarian clear cell carcinomas. Clin Cancer Res 2009, 15(7):2269-2280.

105. Natrajan $R$, Lambros MB, Rodriquez-Pinilla SM, Moreno-Bueno G, Tan DS, Marchio C, Vatcheva R, Rayter S, Mahler-Araujo B, Fulford LG, et al: Tiling path genomic profiling of grade 3 invasive ductal breast cancers. Clin Cancer Res 2009, 15(8):2711-2722.

106. Saito-Ohara F, Imoto I, Inoue J, Hosoi H, Nakagawara A, Sugimoto T, Inazawa J: PPM1D is a potential target for $17 q$ gain in neuroblastoma. Cancer Res 2003, 63(8):1876-1883.

107. Castellino RC, De Bortoli M, Lu X, Moon SH, Nguyen TA, Shepard MA, Rao $\mathrm{PH}$, Donehower LA, Kim JY: Medulloblastomas overexpress the p53-inactivating oncogene WIP1/PPM1D. J Neurooncol 2008, 86(3):245-256

108. Mendrzyk F, Radlwimmer B, Joos S, Kokocinski F, Benner A, Stange DE, Neben K, Fiegler H, Carter NP, Reifenberger G, et al: Genomic and protein expression profiling identifies CDK6 as novel independent prognostic marker in medulloblastoma. J Clin Oncol 2005, 23(34):8853-8862.

109. Ehrbrecht A, Muller U, Wolter M, Hoischen A, Koch A, Radlwimmer B, Actor B, Mincheva A, Pietsch T, Lichter $P$, et al: Comprehensive genomic analysis of desmoplastic medulloblastomas: identification of novel amplified genes and separate evaluation of the different histological components. J Pathol 2006, 208(4):554-563.

110. Hirasawa A, Saito-Ohara F, Inoue J, Aoki D, Susumu N, Yokoyama T, Nozawa S, Inazawa J, Imoto I: Association of 17q21-q24 gain in ovarian clear cell adenocarcinomas with poor prognosis and identification of PPM1D and APPBP2 as likely amplification targets. Clin Cancer Res 2003, 9(6):1995-2004.

111. Fuku T, Semba S, Yutori H, Yokozaki H: Increased wild-type p53-induced phosphatase 1 (Wip1 or PPM1D) expression correlated with downregulation of checkpoint kinase 2 in human gastric carcinoma. Pathol Int 2007, 57(9):566-571.

112. Loukopoulos P, Shibata T, Katoh H, Kokubu A, Sakamoto M, Yamazaki K, Kosuge T, Kanai Y, Hosoda F, Imoto I, et al: Genome-wide array-based comparative genomic hybridization analysis of pancreatic adenocarcinoma: identification of genetic indicators that predict patient outcome. Cancer Sci 2007, 98(3):392-400.

113. Rauta J, Alarmo EL, Kauraniemi $P$, Karhu R, Kuukasjarvi T, Kallioniemi A: The serine-threonine protein phosphatase PPM1D is frequently activated through amplification in aggressive primary breast tumours. Breast Cancer Res Treat 2006, 95(3):257-263.

114. Martin F, Bangham CR, Ciminale V, Lairmore MD, Murphy EL, Switzer WM, Mahieux R: Conference highlights of the 15th International Conference on Human Retrovirology: HTLV and related retroviruses, 4-8 June 2011, Leuven, Gembloux, Belgium. Retrovirology 2011, 8:86.

115. Hayashi R, Tanoue K, Durell SR, Chatterjee DK, Jenkins LM, Appella DH, Appella E: Optimization of a cyclic peptide inhibitor of Ser/Thr phosphatase PPM1D (Wip1). Biochemistry 2011, 50(21):4537-4549.

116. Kern SE, Pietenpol JA, Thiagalingam S, Seymour A, Kinzler KW, Vogelstein B: Oncogenic forms of p53 inhibit p53-regulated gene expression. Science 1992, 256(5058):827-830

117. Choi J, Appella E, Donehower LA: The structure and expression of the murine wildtype p53-induced phosphatase 1 (Wip1) gene. Genomics 2000, 64(3):298-306.

118. Yamano Y, Nagai M, Brennan M, Mora CA, Soldan SS, Tomaru U, Takenouchi $\mathrm{N}$, Izumo S, Osame M, Jacobson S: Correlation of human T-cell lymphotropic virus type 1 (HTLV-1) mRNA with proviral DNA load, virus-specific CD8(+) T cells, and disease severity in HTLV-1-associated myelopathy (HAM/TSP). Blood 2002, 99(1):88-94.

119. Livak KJ, Schmittgen TD: Analysis of relative gene expression data using real-time quantitative PCR and the 2(-Delta Delta $C(T)$ ) Method. Methods 2001, 25(4):402-408.

doi:10.1186/1742-4690-9-114

Cite this article as: Zane et al:: Wip1 and p53 contribute to HTLV-1 Taxinduced tumorigenesis. Retrovirology 2012 9:114. 